\title{
Liver Cancer Stem Cells: A New Paradigm for Hepatocellular Carcinoma Treatment
}

\author{
Shu Kwun Lui, Valery Vilchez and Roberto Gedaly* \\ Department of Surgery, Transplant Division, University of Kentucky, College of Medicine, Lexington, KY 40536, USA
}

\begin{abstract}
Hepatocellular carcinoma (HCC) ranks as fifth most prevalent cancer worldwide. Despite its high prevalence rate the therapeutic options and prognosis of the patients mainly depend on the stage on the presentation. The Cancer Stem Cell (CSC) hypothesis proposes that a small population of cells is responsible for tumour development and disease progression. These cells are characterized by their ability of self-renewal, differentiation, chemo- and radio-resistance. CSC hypothesis could explain HCC heterogeneity within or between masses, its mechanism of recurrence and metastasis, and the poor outcome of current therapies. Due to their role in HCC it might be essential targeting these cells as part of the treatment. Several signaling pathways including RAS/RAF/MAPK, Wnt- $\beta$-catenin, $\mathrm{PI} 3 \mathrm{~K} / \mathrm{mTOR}$, among others; have been implicated in HCC carcinogenesis and their components represent novel molecular therapeutic targets. Because of the heterogeneity of these cancers and the complex process involved in hepatocarcinogenesis, our group and others suggest that combined therapy should be essential in HCC treatment. This review focuses on the current understanding of liver cancer stem cells, their clinical implications, and the rationale for targeting these cells in HCC treatment.
\end{abstract}

Keywords: Hepatocellular carcinoma; Liver cancer stem cells; RAS/ RAF/MAPK; Wnt/ $\beta$-catenin pathway; PI3K/mTOR; Sorafenib

\section{Introduction}

Hepatocellular carcinoma is considered one of the most lethal cancers in the world, ranking as fifth most prevalent cancer and third leading cause of cancer related death. In areas like Japan and Central Europe, HCC prevalence is associated with Hepatitis C Virus (HCV) infection. In Western countries, there is an increased incidence of HCC due to the rise of Hepatitis B Virus (HBV) infections, HCV infections and chronic alcohol use [1,2]. Western's HCC usually developed in cirrhotic liver while over $50 \%$ of Asian countries developed in noncirrhotic liver. More recent studies suggest metabolic syndrome, such as type II diabetes and obesity, is an additional risk factor for development of HCC $[1,2]$.

HCC staging have been established based on the presence of several prognostic factors including tumour size, number of the lesions, patient's health status, liver remnant function, among others [3-5]. Despite HCC's high prevalence, the therapeutic options and prognosis of the patients mainly depends on the stage on the presentation. The earlier stages are treated with resection and/or liver transplantation. However, the tumour recurrence rate has been reported up to $70 \%$ at five years after resection [6]. Intermediate stages are treated with locoregional therapies including radiofrequency ablation (RFA), microwave ablation (MWA) or transarterial chemoembolism (TACE). In those patients with advanced, large non-resectable lesions, Sorafenib is the standard of care. For terminal stage patients, only palliative care is recommended. Unfortunately, there is no approved second line treatment for prevention or recurrence of HCC which empathizes the importance of additional research in this field [7].

The Cancer Stem Cell (CSC) model is growing as a possible alternative hypothesis in tumorigenesis. This hypothesis proposes that a small population of cells is responsible for tumour development and growth. It also propounds to explain tumour metastasis and chemotherapy resistance [2,7]. In recent years, numerous signaling pathways such as RAS/RAF/MAPK, Wnt- $\beta$-catenin, EGFR, insulinlike growth factor receptor, AKT-mTOR, Notch and Hedgehog, among others; have been implicated in hepatocarcinogenesis. Because of that, some of their components could represent important molecular targets for therapy in HCC.

The RAS/RAF/MAPK pathway is typically activated in HCC as a result of increased signaling induced from upstream growth factors and due to inactivation of tumor suppressor genes [1,7]. As previously mentioned, Sorafenib, which significantly inhibit RAS/RAF/MAPK pathway, is the only approved drug that have shown to decrease tumor progression, and improve survival in patients with advanced HCC [7]. Because of the heterogeneity of these cancers and the complex process involved in HCC carcinogenesis, previously published data from preclinical studies suggest that combination therapy could be essential in HCC treatment. There are numerous combination therapy studies for advanced stage HCC ongoing in phases 1-3 and several reagents are being tested targeting novel signaling cascades such as Wnt- $\beta$ catenin and Notch [7-9]. Our group and others have focused on ways of producing inhibition of liver cancer stem cells (LCSC) and differences in resistance patterns with non-LCSC lines [10-13].

Exploring LCSCs and ways to target them could shine a new light in tumourgenesis and new treatment options. This review focuses on the significance and current understanding of LCSCs and the rationale for targeting these cells in HCC treatment.

\section{Stem Cell Hypothesis in Cancer}

There are two major models that have been proposed to define malignant solid tumours: the stochastic and the hierarchical models.

*Corresponding author: Roberto Gedaly, Department of Surgery, Transplant Division, University of Kentucky, College of Medicine, 800 Rose Street, Room C453, Lexington, Kentucky 40536-0293, USA, Tel: (859)-323-4661; Fax: (859)-257-3644; E-mail: rgeda2@uky.edu

Received May 16, 2015; Accepted May 27, 2015; Published May 29, 2015

Citation: Lui SK, Vilchez V, Gedaly R (2015) Liver Cancer Stem Cells: A New Paradigm for Hepatocellular Carcinoma Treatment. J Stem Cell Res Ther 5: 283. doi:10.4172/2157-7633.1000283

Copyright: (c) 2015 Lui SK, et al. This is an open-access article distributed under the terms of the Creative Commons Attribution License, which permits unrestricted use, distribution, and reproduction in any medium, provided the original author and source are credited. 
The stochastic model, also known as clonal evolution model, suggests that undifferentiated cancer cells with the most growth advantages would comprise majority of the tumour. This theory also meant a homogenous cell across the whole mass and that each cell has similar growth potential. On the other hand, the hierarchical model, or the CSC hypothesis, suggests the existence of a subpopulation of cells that can maintain or expand the tumour putting these stem cells at the apex of the cell differentiation hierarchy [2]. The stem cells are characterized by their capacity of self-renewal, differentiation, and tumourgenicity. These cells are also regarded to be more resistant to chemotherapy and radiotherapy [14-16].

A cancer stem cell can be a differentiated cell that acquires selfrenewal abilities despite the parallel observed between a stem cell and CSC [16]. Interestingly, the two models are not mutually exclusive as there are evidences supporting both. Homogenous tumours can be found and it has been shown that CSC can expand via clonal evolution methods [16]. A CSC can go on clonal evolution to produce a more aggressive second generation CSC to replace or metastasize to other locations. It is reported that serial transplantation of CSC can select for a more aggressive generation [16,17].

The existence of CSC was first proposed decades ago by John Dick et al. who were the first to demonstrate the role of stem cells in hematological malignancies [18]. Since then substantial evidence has emerged to support tumor heterogeneity and cellular hierarchy within a tumor in solid cancers. Recently, studies have provided convincing evidence that these cells do exist in solid tumors of many types including, brain, breast, colorectal, hepatobiliary, pancreas and prostate cancers [19-24]

Normal stem cells (NSC) are believed to reside in a "stem cell niche" which plays a crucial role in some of their typical characteristics such as pluripotency and self-renewal [25]. Recent studies suggest that CSC also rely on a vascularized complex, which control their differentiation and proliferation $[16,26]$. This liver tumor microenvironment is a complex mixture of tumoral cells within the extracellular matrix (ECM), combined with an intricate mix of stromal cells. Together, these elements contribute to the carcinogenic process by sustaining proliferative signaling, evading growth suppressors, resisting cell death, inducing angiogenesis, activating invasion and metastasis, reprogramming energy metabolism, and eluding immune destruction [27].

The CSC hypothesis is promising due to how well it fits with the clinical presentation of HCC. It explains the tumour's heterogeneity within or between masses and its mechanism of relapse and metastasis. It can also explain the poor outcome of current therapy [24].

\section{Characterization of Liver Cancer Stem Cells}

Tumour markers have been a mainstay of identifying cancer cells in all tissues. The expression of markers was first studied in leukemia stem cells. In solid tumours, it is a topic under heavy research. Because some of these markers can be found in normal tissues, it is crucial to find more specific markers or use several of them to identify LCSCs. Screenings on several LCSC markers demonstrated a wide heterogeneity of expression profile of the markers in HCC's CSC. No consistent expression patterns of LCSC stem markers between or within cell lines were found, suggesting a strong heterogeneity between HCC and perhaps their origins. Therefore, a universal LCSC for HCC is most likely non-existent due to this heterogeneity. To date, it has been reported that LCSCs can be recognised by multiple cell surface antigens including CD133, CD90, CD44, CD24, and the epithelial cell adhesion molecule (EpCAM) [28-32] (Table 1).

Due to the heterogeneity of LCSC markers other features have been identified to help characterize these cells. Initiation studies have been performed using small number of LCSCs to produce aggressive HCC in vivo [13]. Resistance to therapy studies have been used to recognize CSC that are usually more resistant than non-CSC counterparts. Genetic studies to demonstrate usual genes and signaling pathways known to be associated with survival and maintenance of CSCs have been performed to better characterize these cells $[1,2,9]$.

\section{EpCAM (CD326)}

EpCAM is a surface antigen that is normally expressed in human epithelial tissues, progenitor, and stem cells. In regards to the liver, it is expressed in embryonic hepatoblasts, bile duct epithelium, hepatic stem cells, premalignant tissues, and HCC. It is not expressed in normal non fetal hepatocytes therefore it is considered a prospective marker for premalignant tissues or HCC [28]. EpCAM is a weak homotypic cell adhesion molecule. Its oncogenic potential comes from its intracellular domain EpICD where EpCAM is cleaved. EpICD can then bind with proteins such as $\beta$-catenin, Lef, and FHL2 and upregulate the transcription of oncogenes [28].

EpCAM has been identified to be associated with Wnt/ $\beta$-catenin pathway, and several studies have stablished that inhibition of $\mathrm{Wnt} / \beta$ catenin pathway leads to a decrease expression of EpCAM [33-36]. The signalling between EpCAM and Wnt/ $\beta$-catenin pathway is not completely understood [33] but there is evidence that microRNA-181a plays a role in this missing link [35].

EpCAM is best used alongside other more prominent markers

\begin{tabular}{|c|c|c|c|}
\hline Marker & Expression in healthy tissue & Expression on cancer type & Malignant Properties in $\mathrm{HCC}$ \\
\hline CD19 & B lymphocytes & B cell malignancies & \\
\hline CD20 & B lymphocytes & Melanoma & \\
\hline CD24 & B lymphocytes, neuroblasts & Pancreas, lung and liver cancer, negative on breast cancer & $\begin{array}{l}\text { Metastasis } \\
\text { Highly associated with Wnt/ } \beta \text {-catenin pathway }\end{array}$ \\
\hline CD34 & Endothelial and hematopoietic progenitors & Hematopoietic malignancies & \\
\hline CD38 & Multiple stages of B and T cells & Negative on AML & \\
\hline CD44 & Broadly on many tissues & Liver, colorectal, breast, pancreas, head and neck cancers & $\begin{array}{l}\text { Metastasis } \\
\text { Highly associated with Wnt/ } \beta \text {-catenin pathway }\end{array}$ \\
\hline CD90 & T cells, neurons & Liver and colorectal cancer & Metastasis \\
\hline CD133 & Proliferative cells in multiple organs & Liver, colorectal, lung, liver and brain cancer & $\begin{array}{l}\text { Proliferation } \\
\text { Highly associated with Wnt/ } \beta \text {-catenin pathway }\end{array}$ \\
\hline EрСАM & Panepithelial marker & Liver, colorectal and pancreatic cancer & $\begin{array}{l}\text { Metastasis } \\
\text { Highly associated with Wnt/ } \beta \text {-catenin pathway }\end{array}$ \\
\hline
\end{tabular}

Adapted from Clevers H (2011) The cancer stem cell: premises, promises and challenges. Nature Medicine 17: 313-319.

Table 1: Surface markers used for the identification of cancer stem cells. 
like alpha-fetoprotein (AFP) and is commonly present with CD133. $\mathrm{EpCAM}^{+} \mathrm{AFP}^{+} \mathrm{HCCs}$ were found to have poor prognosis with high metastasis and stem cell associated gene expressions. Shan et al. proved an increase in microvessel density and VEGF level in $\mathrm{EpCAM}^{+} \mathrm{AFP}^{+}$ HCC [37].

\section{CD133 (Prominin 1)}

CD133, a 5-transmembrane glycoprotein, is widely used as a cancer marker in many tissues such as brain, kidney, bone marrow, liver, kidney, and pancreas. It is found in fetal liver cells, bone marrow, and adult blood cells [29]. CD133 ${ }^{+}$HCC characterizes by having high proliferative and tumorigenic potentials as well as lower levels of mature hepatocyte markers [30]. CD133 ${ }^{+}$HCCs from Huh7, HepG2, and PLC cell lines exhibited cancer and stem cell like properties in vivo [38].

Ma et al. used a partial hepatectomy model in mice to study the role of stem cells in liver regeneration. They found that CD133 was significantly upregulated in association with the liver regeneration process [38]. In subsequent studies, $\mathrm{CD}_{133^{+}}$cells displayed greater tumourgenicity in immunodeficient mice, higher colony forming efficiency and proliferation ability, and capacity to differentiate into non-hepatocyte-like lineages, indicative of their multipotency $[30,39]$. Further studies demonstrated that these cells were more resistant to conventional cytotoxic treatments than their CD133 counterparts [40]. This resistance may contribute to tumour metastases and relapse.

\section{CD44}

CD44 is a cell surface glycoprotein interacting with extracellular structures such as hyaluronic acid for cell-cell contact, cell adhesion and migration. It undergoes alternative splicing resulting in several isoforms participating in different cellular functions, including lymphocyte recirculation, homing, and T-lymphocyte activation. It also interacts with $\mathrm{Wnt} / \beta$-catenin pathway inducing cell proliferation, migration, and apoptosis [41]. Similar to the other markers, it can be found in many malignant cancers, for instance, gallbladder carcinoma, renal cell carcinoma, colorectal cancer, and HCC [31,41-44]. CD44 ${ }^{+}$ tumour cells are related with metastasis and in LCSCs, they are found to be associated with tumor invasiveness [45]. CD44 has been increasingly implicated as a marker for tumor-initiating stem cells and associated with poor prognosis in HCC and other solid tumours [31,32,41,44-46].

\section{CD90 (Thy-1)}

CD90 is an N-glycosylated, glycophosphatidylinositol anchored cell surface protein used as a marker for several kinds of stem cells [11]. Its function is to regulate cell-cell and cell-matrix interactions in neuronal cells, fibroblasts, endothelial cells, thymocytes, among others. CD90 is a promoter of melanoma and leukocytes migration and metastasis [11]. In the fetal liver, CD90 has been expressed in liver hematopoietic cells, suggesting its role in HCC as a marker of metastasis rather than inhibition [47,48].

\section{CD24}

CD24 is a cell adhesion protein also anchored to the cell membrane by glycosylphosphatidylinositol. It binds to P-selectin on endothelial cells and platelets, which has been associated with development of tumour metastasis $[49,50]$. In HCC cells, expression of CD24 has been correlated with accumulation of $\beta$-catenin leading to the activation of its oncogenic pathway [49].

Interestingly, $\mathrm{CD} 24$ plays a role in acquiring chronic $\mathrm{HBV}$ infection, a prominent cause of HCC. Li et al. identified the P170 ${ }^{T / T}$ CD24 mutation is more prevalent in chronic HBV infected patients compared to patients without the infection. This marker is also linked with an earlier onset of HCC. In the same study, the authors demonstrated that P1527 ${ }^{\text {del }}$ allele, leading to a decrease in CD24 expression, is correlated with decrease in HBV infection [51].

\section{Clinical Implications of Liver Cancer Stem Cells in Hepatocellular Carcinoma}

HCC diagnosis is based on imaging studies supported by measuring serum AFP levels [52]. While these tools are effective for screening and diagnosis of HCC, their use for malignancy and recurrence detection is limited. It has been described that normal serum AFP levels postoperatively do not reflect total resection of HCC from the patient [53,54], and about $20 \%$ of HCC does not increase serum AFP levels. Additional markers such as GPC3, GGT II, AFU, TGF- $\beta 1$, and TSGF may help improve accuracy but are not reliable by themselves [55]. This brings in the need to find additional markers for postoperative detection and assessment of patient's prognosis. Using progenitor stem cells markers can be beneficial for these purposes. Moreover, cells with these markers which are link to other stem cell characteristics could be used as potential therapeutic targets.

As previously mentioned, $\mathrm{CD} 133$ has been one of the major markers for poor prognosis found in HCC [30,38-40]. Patients undergoing resection for HCC with $\mathrm{CD}_{133^{+}}$lesions have shorter overall survival and higher recurrence rate compared to patients with CD133- tumors $[56,57]$. CD133 expression has been associated with the ability to survive in hypoxic and poor nutritional environment through autophagy [58]. There is also evidence that CD133 expression is correlated with poorer tumour response to Sorafenib [59].

CD90 expression in LCSC is indicated as a marker of metastasis $[47,48]$, and described to play a role in enhancing the motility of $\mathrm{EpCAM}^{+}$by TGF- $\beta$ signalling pathway [60]. Some studies showed a correlation between the level of CD90 expression in LCSC and stages for liver disease progression [61]. Interestingly, CD90 seems to be upregulated in HBV infections triggered HCC and increased CD90 expression is correlated with poor prognosis [62].

CD44 expression is associated with metastasis [24] and some CD44 variant, such as CD44v6, are reported to interact with c-Met to sustain RAS signalling pathway for cell proliferation [63]. Its association with metastasis is related to its role in the epithelial-mesenchymal transition (EMT) [64-68], leading to loss of cell-cell adhesion and gain migratory with invasive properties. The expression of CD44 was found to be responsible for recurrence after local ablation therapy of HCC due to its association with EMT [68].

Cells co-expressing CD133 and CD90 with CD44 are more aggressive than those expressing CD133 or CD90 alone [2]. Interestingly, $\mathrm{CD} 133^{+} \mathrm{CD} 44^{+}$cells exhibit preferential expression of some stem cell associated genes ( $\beta$-catenin and Bmi- 1$)$ and are more resistant to chemotherapeutic agents through up-regulation of ATPbinding cassette $(\mathrm{ABC})$ superfamily transporters. Zhu et al. compared CD133 ${ }^{+} \mathrm{CD} 44^{-}$cells with $\mathrm{CD} 133^{+} \mathrm{CD} 44^{+} \mathrm{HCC}$ cells, and found that double positive cells are more tumorigenic and chemo resistant, and express a higher level of stemness-associated genes [69]. Further, it was recently published that $\mathrm{CD} 133^{+} \mathrm{CD} 44^{+}$cells defined a subgroup of tumor cells that could be responsible for hematogenous metastasis of liver cancers [24].

Our group demonstrated high tumourgenicity and aggressiveness using $\mathrm{CD} 133^{+}, \mathrm{CD} 44^{+}$and CD24+ LCSCs. We inoculated 2000 of these 
Citation: Lui SK, Vilchez V, Gedaly R (2015) Liver Cancer Stem Cells: A New Paradigm for Hepatocellular Carcinoma Treatment. J Stem Cell Res Ther 5: 283. doi:10.4172/2157-7633.1000283

Page 4 of 7

LCSCs, and visible tumors were developed 4 to 6 weeks after injection in all mice [10]. Previous studies showed that using other non-LCSC lines such $\mathrm{HuH} 7$, millions of cells are needed to develop tumors in nude mice. The developed tumors showed pleomorphic cells growing with significant amount of mitosis, all features of poorly differentiated HCC. Moreover, our findings revealed that dual inhibition of PI3K/mTOR and RAS/RAF/MAPK signaling pathways is superior to monotherapy in non-LCSC (PLC, HEP3B and HuH7) and LCSC lines $\left(\mathrm{CD} 133^{+}\right.$, $\mathrm{CD}_{4} 4^{+}$and $\left.\mathrm{CD} 24^{+}\right)[10]$.

Fan et al. proposed that LCSC markers found in blood can be an additional prognostic indicator for HCC prognosis. They detected $\mathrm{CD} 45 \mathrm{CD}^{\circ} 0^{+} \mathrm{CD} 44^{+} \mathrm{CSC}$ in $\mathrm{HCC}$ patients and described a high correlation between the presence of these circulating cells in blood and HCC recurrence. Patients with $>0.01 \%$ circulating LCSCs have a $22.7 \% 2$-year recurrence free survival rate versus $64.2 \%$ in patients with $<0.01 \%$ circulating LCSCs [70]. Similar poor prognosis was reported with circulating LCSC expressing EpCAM [71].

Recently, our group studied the expression of CD44 and/or CD133 as predictors of prognosis in patients undergoing transplantation for HCC. Using immunofluorescence, we found that $\mathrm{CD} 133$ and CD44 positivity is associated with increased occurrence of moderate to poorly differentiated HCC and elevated levels of AFP. These markers in combination with the presence of microvascular invasion (MVI) were independently correlated with poor overall survival and increased risk of recurrence after transplantation for HCC (data not published) (Figure 1).
These early results suggest that molecular characterization of these markers could eventually augment the anatomic staging of primary liver malignancies, although further studies are warranted to elucidate the association of LCSCs and tumor biology and their impact in HCC prognosis and treatment.

\section{LCSCs: Potential Molecular Targets for HCC Therapy?}

The failed cytotoxic chemotherapy in HCC and the development of Sorafenib as standard of care for management of advanced nonresectable lesions have significantly stimulated the understanding of the different cell signaling pathways involved in hepatocarcinogenesis. Focus on targeting CSCs should bring important and revolutionary advances in cancer therapeutics. As previously mentioned, LCSC markers are expressed erratically among HCCs and the effectiveness of targeting these cells could be largely variable. However, due to their role in tumour progression, recurrence, and metastasis it might be essential targeting these cells as part of HCC treatment.

As CD133 being one of the major and well-studied marker for HCC, several potential therapeutic approaches have been proposed for targeting LCSC with CD133 expression. Smith et al. tested a murine anti-human CD133 antibody conjugated to monomethyl auristatin F, a cytotoxic drug, and significantly inhibited the growth of Hep3B HCC cells [72]. Zhang et al. used an inhibitory transcription factor named Ikaros to repress the expression of CD133 through direct binding to CD133 P1 promoter leading to a decreased in tumourgenicity of LCSC
CD44

A

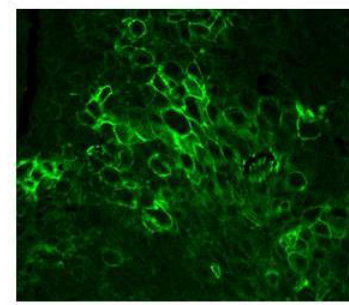

B

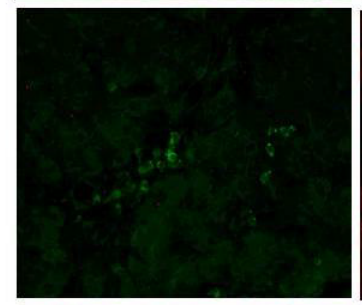

C

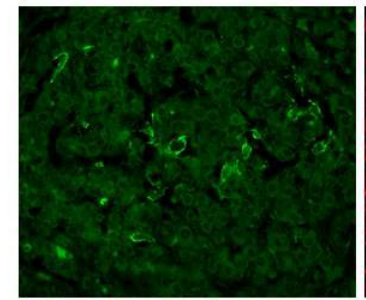

CD133
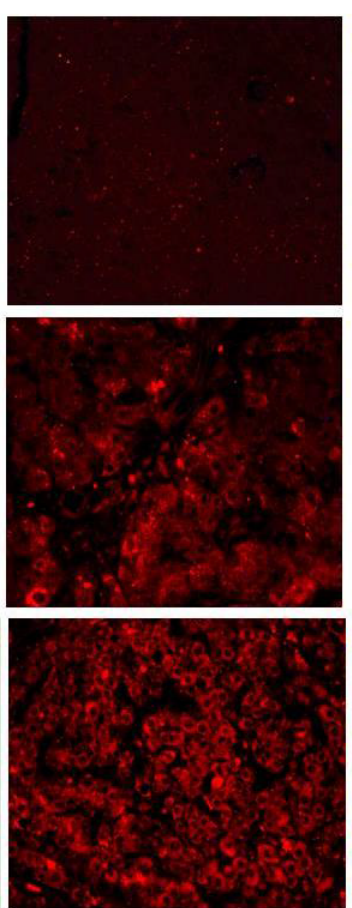

CD44/CD133
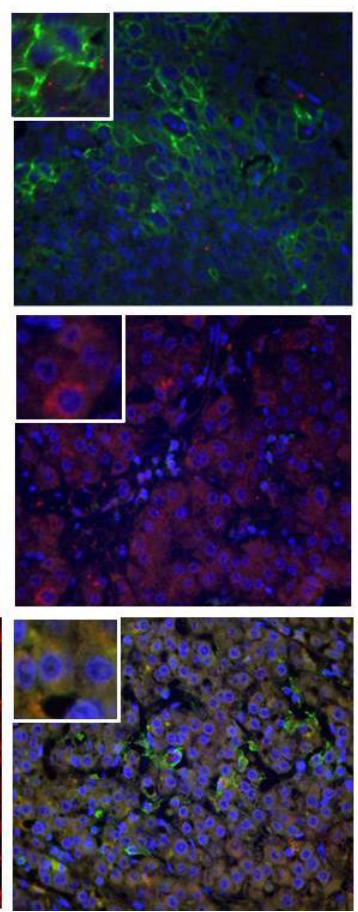

H\&E Staining
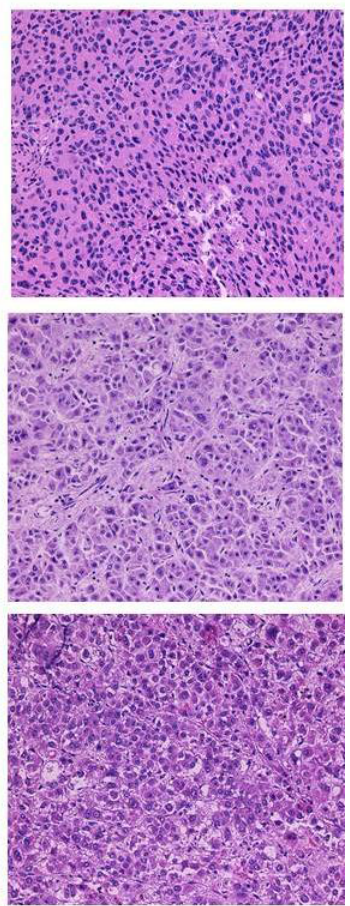

Figure 1: Illustration of liver cancer stem cells immunofluorescence microscopy and H\&E staining of explanted livers. A. Sixty year old male diagnosed with a solitary stage II HCC $\left(\mathrm{CD}_{4} 4^{+}\right)$, AFP level $4.8 \mathrm{mg} / \mathrm{dl}$, recurrence-free survival of 128 months. H\&E staining demonstrate a moderate to poorly differentiated tumor. B. Fortyeight year old male diagnosed with multiple stage II HCC $\left(\mathrm{CD} 133^{+}\right)$, AFP level $2.5 \mathrm{mg} / \mathrm{dl}$ recurrence-free survival of $93 \mathrm{months}$. H\&E staining demonstrate a welldifferentiated tumor. C. Fifty five year old male diagnosed with a solitary stage I HCC $\left(\mathrm{CD} 44^{+} / \mathrm{CD} 133^{+}\right)$, AFP level $3.6 \mathrm{mg} / \mathrm{dl}$, recurrence-free survival of $39 \mathrm{months}$. H\&E staining demonstrate a moderate to poorly differentiated tumor. Expression of stem cell markers was reported as single CD44 positive, CD133 positive or dual pattern of immunofluorescence positivity when expression of both markers was identified in the same cell. Magnified are represents tumor cells with positive LCSC markers. H\&E magnification of $20 X$. 
in HCC [73]. Bach et al. used an oncolytic measles virus to target CD133+ LCSC showing an antitumoral effect on the HCC growing subcutaneously or multifocally in the peritoneal cavity of severe combined immunodeficient mice [74].

In another study, Ma et al. documented that activation of the Akt/ $\mathrm{PKB}$ and Bcl-2 pathway contributes to the chemoresistance observed in $\mathrm{CD} 133^{+} \mathrm{HCC}$ cells [40]. Interestingly, treatment with an Akt 1 inhibitor sensitized $\mathrm{CD} 133^{+}$HCC cells to conventional anti-cancer treatment with drugs such as 5-FU [40]. Other authors reported that treating $\mathrm{CD} 90^{+}$cells with anti-human CD44 antibody induced cell apoptosis in a dose-dependent manner in immunodeficient mice, suppressing tumor nodule formation in liver and metastatic lesions in lung [48,75].

Current strategies are focused on targeting rapidly proliferating tumor cells and also likely the differentiated tumor cells. Treatment seem to be initially successful, but often fail to provide a long lasting effect probably because these are very heterogeneous cancers with diverse cells with significant different sensitivities.

The RAS/RAF/MAPK pathway is one of the best studied signalling pathway and main target of Sorafenib. Chronic activation or mutations in this pathway leads tumour cell proliferation and tumour angiogenesis [76]. Looking at the same direction as Sorafenib, it would be beneficial to target other signalling pathways to co-inhibit along with the RAS/ RAF/MAPK. Our group have published that HCC cell lines, PLC, Hep3B and Huh7, have different sensitivities to Sorafenib and PKI-587, a dual PI3K/mTOR inhibitor. Interestingly, LCSC cell line showed at least moderate to severe resistance to these drugs in vitro. Our findings demonstrated that dual inhibition of $\mathrm{PI} 3 \mathrm{~K} / \mathrm{mTOR}$ and RAS/RAF/ MAPK signaling pathways is superior to monotherapy in non-LCSC and LCSC lines (CD133+, CD44 ${ }^{+}$and CD24 $\left.4^{+}\right)$[10].

The Wnt $/ \beta$-catenin pathway appears as another significant pathway to target because of its prevalence in HCC [77]. $\beta$-catenin is a transcriptional coactivator in the TCF/LEF family. It is normally bound to a destructive complex composed of Axin, Adenomatosis polyposis coli (APC), protein phosphatase 2A (PP2A0), glycogen synthase kinase $3 \beta$ (GSK3 $\beta$ ), and casein kinase $1 \alpha(\mathrm{CK} 1 \alpha)$ leading to its ubiquitination. The activation of the pathway starts with the binding of Wnt protein binding to the Fizzled (Fzz) and LRP5/6 co-receptors. The binding activates Dishevelled (Dvl) leading to an inhibition of GSK-3 $\beta$ and breakdown of the destructive complex, freeing $\beta$-catenin. Accumulation of $\beta$-catenin in cytoplasm leads to localization to the nucleus, displacement of Groucho-HDAC co-repressors, and recruitment of LEF/TCF DNA binding factors. This chain of events subsequently leads to transcription of oncogenes such as c-myc, Survivin, and cyclin D1 which promotes cell proliferation and inhibit apoptosis. More than $50 \%$ of HCC has an accumulation of $\beta$-catenin and more than $20 \%$ of HCCs have $\beta$-catenin related mutations [78].

Due to the importance of $\beta$-catenin pathway in CSC we initiated an in vitro model using FH535 to block Wnt/ $\beta$-catenin pathway in LCSC $\left(\mathrm{CD} 133^{+}, \mathrm{CD}_{4} 4^{+}, \mathrm{CD} 24^{+}\right)$. We demonstrated significant inhibition of proliferation and luciferase with FH535 (Wnt/ $\beta$-catenin and PPAR inhibitor) in these $\mathrm{CD}_{133^{+}}, \mathrm{CD} 44^{+}, \mathrm{CD} 24^{+}$cells. RT-PCR showed inhibition of Cyclin D21, and p21 and Survivin expression using FH535 [12]. Moreover, in a different study, our group published the synergistic effect of FH535 and Sorafenib in combination on inhibition of LCSC's proliferation. On Western Blot analysis we demonstrated enhanced cleaved poly (ADP-ribose) polymerase (PARP) and inhibition of cyclin $\mathrm{D} 1, \mathrm{Bcl} 2$, Survivin and c-myc with this combination [13].

In conclusion, $\mathrm{HCC}$ has proven to be a very heterogeneous disease and hepatocarcinogenesis remains a very complex process, with multiple factors involved in its origin. According to the cancer stem cells hypothesis cancer initiation, progression, recurrence, metastasis and therapy resistance are unique properties implicit on CSC subsets. RAS/ RAF/MAPK, Wnt- $\beta$-catenin, EGFR, PI3K/mTOR, Notch, Hedgehog, among others signalling pathways are related to carcinogenesis and their components represent molecular targets for therapy in HCC.

The management of HCC has changed substantially in the recent times, and the development of Sorafenib represented a significant breakthrough that has prompted further expansion on moleculartargeted therapies that potentially inhibit different pathways. Because of the heterogeneity of these cancers and the complex process involved in HCC carcinogenesis, our group and others suggest that combination therapy should be essential in HCC treatment. Our group and others demonstrated that patterns of response to combined therapy are different between both non-LCSC and LCSC cell lines. We proved the efficacy of combination therapy over monotherapy, and synergism using the combination of $\beta$-catenin and PI3K/mTOR inhibitors and Sorafenib for inhibiting non-LCSC and LCSC HCC cell line.

Focusing on targeting CSCs should bring important and revolutionary advances in cancer therapy. However, the understanding of LCSCs still remains limited and further studies are warranted to assess their association with HCC prognosis and their potential as targets of molecular therapy.

\section{References}

1. Galuppo R, Ramaiah D, Ponte OM, Gedaly R (2014) Molecular therapies in hepatocellular carcinoma: what can we target? Dig Dis Sci 59: 1688-1697. [PubMed]

2. Ji J, Wang XW (2012) Clinical implications of cancer stem cell biology in hepatocellular carcinoma. Semin Oncol 39: 461-472. [PubMed]

3. Pawlik TM, Delman KA, Vauthey JN, Nagorney DM, Ng IO, et al. (2005) Tumor size predicts vascular invasion and histologic grade: Implications for selection of surgical treatment for hepatocellular carcinoma. Liver Transpl 11: 1086-1092. [PubMed]

4. McHugh PP, Gilbert J, Vera S, Koch A, Ranjan D, et al. (2010) Alpha-fetoprotein and tumor size are associated with microvascular invasion in explanted livers of patients undergoing transplantation with hepatocellular carcinoma. HPB 12 56-61. [PubMed]

5. Han DH, Choi GH, Kim KS, Choi JS, Park YN, et al. (2013) Prognostic significance of the worst grade in Hepatocellular carcinoma with heterogeneous histologic grades of differentiation. J Gastroenterol Hepatol 28: 1384-1390. [PubMed]

6. Llovet JM, Schwartz M, Mazzaferro V (2005) Resection and liver transplantation for hepatocellular carcinoma. Semin Liver Dis 25: 181-200. [PubMed]

7. Llovet JM, Bruix J (2008) Molecular targeted therapies in hepatocellular carcinoma. Hepatology 48: 1312-1327. [PubMed]

8. Lachenmayer A, Toffanin S, Cabellos L, Alsinet C, Hoshida Y, et al. (2012) Combination therapy for hepatocellular carcinoma: additive preclinical efficacy of the HDAC inhibitor panobinostat with sorafenib. J Hepatol 56: 1343-1350. [PubMed]

9. Mínguez B, Tovar V, Chiang D, Villanueva A, Llovet JM (2009) Pathogenesis of hepatocellular carcinoma and molecular therapies. Curr. Opin. Gastroenterol 25: 186-194. [PubMed]

10. Gedaly R, Angulo P, Hundley J, Daily MF, Chen C, et al. (2012) PKI-587 and sorafenib targeting PI3K/AKT/mTOR and Ras/Raf/MAPK pathways synergistically inhibit HCC cell proliferation. J Surg Res 176: 542-548. [PubMed]

11. Rege TA, Hagood JS (2006) Thy-1 as a regulator of cell-cell and cell-matrix interactions in axon regeneration, apoptosis, adhesion, migration, cancer, and fibrosis. FASEB J 20: 1045-1054. [PubMed]

12. Gedaly R, Galuppo R, Daily MF, Shah M, Maynard E, et al. (2014) Targeting the $W n t / \beta$-catenin signaling pathway in liver cancer stem cells and hepatocellula carcinoma cell lines with FH535. PLoS One 9: e99272. [PubMed] 
Citation: Lui SK, Vilchez V, Gedaly R (2015) Liver Cancer Stem Cells: A New Paradigm for Hepatocellular Carcinoma Treatment. J Stem Cell Res Ther 5: 283. doi:10.4172/2157-7633.1000283

Page 6 of 7

13. Galuppo R, Maynard E, Shah M, Daily MF, Chen C, et al. (2014) Synergistic inhibition of HCC and liver cancer stem cell proliferation by targeting RAS/RAF/ MAPK and WNT/ $\beta$-catenin pathways. Anticancer Res 34: 1709-1713. [PubMed]

14. Dean M, Fojo T, Bates S (2005) Tumour stem cells and drugresistance. Nat Rev Cancer 5: 275-284. [PubMed]

15. Rich JN (2007) Cancer stem cells in radiation resistance. Cancer Res 67: 89808984. [PubMed]

16. Visvader JE, Lindeman GJ (2008) Cancer stem cells in solid tumours: accumulating evidence and unresolved questions. Nat Rev Cancer 8: 755-768. [PubMed]

17. Barabe F, Kennedy JA, Hope KJ, Dick JE (2007) Modeling the initiation and progression of human acute leukemia in mice. Science 316: 600-604. [PubMed]

18. Lapidot T, Sirard C, Vormoor J, Murdoch B, Hoang T, et al. (1994) A cell initiating human acute myeloid leukaemia after transplantation into SCID mice. Nature 367: 645-648. [PubMed]

19. Nadal R, Ortega FG, Salido M, Lorente JA, Rodriguez-Rivera M, et al. (2013) CD133 expression in circulating tumor cells from breast cancer patients: potential role in resistance to chemotherapy. Int J Cancer 133: 2398-2407. [PubMed]

20. Wang Q, Chen ZG, Du CZ, Wang HW, Yan L, et al. (2009) Cancer stem cell marker CD133+ tumour cells and clinical outcome in rectal cancer. Histopathology 55: 284-293. [PubMed]

21. Fan L, He F, Liu H, Zhu J, Liu Y, et al. (2011) CD133: a potential indicator for differentiation and prognosis of human cholangiocarcinoma. BMC Cancer 11: 320. [PubMed]

22. Kim HJ, Kim MJ, Ahn SH, Son BH, Kim SB, et al. (2011) Different prognostic significance of CD24 and CD44 expression in breast cancer according to hormone receptor status. Breast 20: 78-85. [PubMed]

23. Mizugaki H, Sakakibara-Konishi J, Kikuchi J, Moriya J, Hatanaka KC, et al. (2013) CD133 expression: a potential prognostic marker for non-small cell lung cancers. Int J Clin Oncol 39: 1070-1081.

24. Hou Y, Zou Q, Ge R, Shen F, Wang Y (2012) The critical role of CD133+CD44+/ high tumor cells in hematogenous metastasis of liver cancers. Cell Research 22: 259-272. [PubMed]

25. Yi SY, Hao YB, Nan KJ, Fan TL (2013) Cancer stem cells niche: A target for novel cancer therapeutics. Cancer Treat Rev 39: 290-296. [PubMed]

26. Boral D, Nie D (2012) Cancer stem cells and niche mircoenvironments. Front Biosci (Elite Ed) 4: 2502-2514. [PubMed]

27. Hanahan D, Coussens LM (2012) Accessories to the crime: functions of cells recruited to the tumor microenvironment. Cancer Cell 21: 309-322. [PubMed]

28. Maetzel D, Denzel S, Mack B, Canis M, Went P, et al. (2009) Nuclear signalling by tumour-associated antigen EpCAM. Nature Cell Biology 11: 162-171. [PubMed]

29. Yin AH, Miraglia S, Zanjani ED, Almeida-Porada G, Ogawa M, et al. (1997) AC133, a novel marker for human hematopoietic stem and progenitor cells. Blood 90: 5002-5012. [PubMed]

30. Suetsugu M, Nagaki H, Aoki T, Motohashi T, Kunisada H, et al. (2006) Characterization of CD133p hepatocellular carcinoma cells as cancer stem/ progenitor cells. Biochem Biophys Res Commun 351: 820-824. [PubMed]

31. Dan T, Hewitt SM, Ohri N, Ly D, Soule BP, et al. (2014) CD44 is prognostic for overall survival in the $\mathrm{NCl}$ randomized trial on breast conservation with 25 year follow-up. Breast Cancer Res Treat 143: 11-18. [PubMed]

32. Galizia G, Gemei M, Del Vecchio L, Zamboli A, Di Noto R, et al. (2012) Combined CD133/CD44 Expression as a Prognostic Indicator of Disease-Free Survival in Patients with Colorectal Cancer. Arch Surg 147: 18-24. [PubMed]

33. Yamashita T, Budhu A, Forgues M, Wang XW (2007) Activation of hepatic stem cell marker EpCAM by Wnt-beta-catenin signaling in hepatocellular carcinoma. Cancer Res 67: 10831-10839. [PubMed]

34. Terris B, Cavard C, Perret C (2010) EpCAM, a new marker for cancer stem cells in hepatocellular carcinoma. J Hepatol 52: 280-281. [PubMed]

35. Ji J, Yamashita T, Budhu A, Forgues M, Jia HL, et al. (2009) Identification of microRNA-181 by genome-wide screening as a critical player in EpCAMpositive hepatic cancer stem cells. Hepatology 50: 472-480. [PubMed]
36. Yamashita T, Ji J, Budhu A, Forgues M, Yang W, et al. (2009) EpCAM-positive hepatocellular carcinoma cells are tumor-initiating cells with stem/progenitor cell features. Gastroenterology 136: 1012-1024. [PubMed]

37. Shan YF, Huang YL, Xie YK, Tan YH, Chen BC, et al. (2011) Angiogenesis and clinicopathologic characteristics in different hepatocellular carcinoma subtypes defined by EpCAM and $\alpha$-fetoprotein expression status. Med Oncol 28: 10121016. [PubMed]

38. Ma S, Chan KW, Hu L, Lee TKW, Wo JYH, et al. (2007) Identification and characterization of tumorigenic liver cancer stem/progenitor cells Gastroenterology 132: 2542-2556. [PubMed]

39. Yin S, Li J, Hu C, Chen X, Yao M, et al. (2007) CD133 positive hepatocellular carcinoma cells possess high capacity for tumorigenicity. Int J Cancer 120 1444-1450. [PubMed]

40. Ma S, Lee TK, Zheng BJ, Chan KW, Guan XY (2008) CD133+ HCC cancer stem cells confer chemoresistance by preferential expression of the Akt/PKB survival pathway. Oncogene 27: 1749-1758. [PubMed]

41. Naor D, Nedvetzki S, Golan I, Melnik L, Faitelson Y (2002) CD44 in cancer. Crit Rev Clin Lab Sci 39: 527-579. [PubMed]

42. Jin L, Hope K, Zhai Q, Smadja-Joffe F, Dick JE (2006) Targeting of CD44 eradicates human acute myeloid leukemic stem cells. Nat Med 12: 1167-1174 [PubMed]

43. Leung EL, Fiscus RR, Tung JW, Tin VP, Cheng LC, et al (2010) Non-small cell lung cancer cells expressing CD44 are enriched for stem cell-like properties. PLoS ONE 5: e14062. [PubMed]

44. Haraguchi N, Ohkuma M, Sakashita H, Matsuzaki S, Tanaka F, et al (2008) CD133+ CD44+ population efficiently enriches colon cancer initiating cells. Ann Surg Oncol 15: 2927-2933. [PubMed]

45. Tovuu LO, Imura S, Utsunomiya T, Morine Y, Ikemoto T, et al. (2013) Role of CD44 expression in non-tumor tissue on intrahepatic recurrence of hepatocellular carcinoma. Int J Clin Oncol 18: 651-656. [PubMed]

46. Piscuoglio S, Lehmann FS, Zlobec I, Tornillo L, Dietmaier W, et al. (2012) Effect of EpCAM, CD44, CD133 and CD166 expression on patient survival in tumours of the ampulla of Vater. J Clin Pathol 65: 140-145. [PubMed]

47. Masson NM, Currie IS, Terrace JD, Garden OJ, Parks RW, et al. (2006) Hepatic progenitor cells in human fetal liver express the oval cell marker Thy-1. Am J Physiol Gastrointest Liver Physiol 291: G45-54. [PubMed]

48. Yang ZF, Ho DW, Ng MN, Lau CK, Yu WC, et al. (2008) Significance of CD90+ cancer stem cells in human liver cancer. Cancer Cell 13: 153-166. [PubMed]

49. Lim SC (2005) CD24 and human carcinoma: tumor biological aspects. Biomed Pharmacother 59: 351-354. [PubMed]

50. Yang XR, Xu Y, Yu B, Xhou J, Li JC, et al. (2009) CD24 is a novel predictor for poor prognosis of hepatocellular carcinoma after surgery. Clin Cancer Res 15 5518-5527. [PubMed]

51. Li D, Zheng L, Jin L, Zhou Y, Li H, et al. (2009) CD24 polymorphisms affect risk and progression of chronic hepatitis B virus infection. Hepatology 50: 735-742. [PubMed]

52. Bialecki ES, Di Bisceglie AM (2005) Diagnosis of hepatocellular carcinoma HPB 7: 26-34. [PubMed]

53. Andorno E, Salizzoni M, Schieroni R, De Hemptinne B (1989) Role of serum alpha-fetoprotein in pre- and post-orthotopic liver transplantation (OLT) for malignant disease. J Nucl Med Allied Sci 33: 132-134. [PubMed]

54. Johnson PJ, Williams R (1980) Serum alpha-fetoprotein estimations and doubling time in hepatocellular carcinoma: influence of therapy and possible value in early detection. J Natl Cancer Inst 64: 1329-1332. [PubMed]

55. Zhou L, Liu J, Luo F (2006) Serum tumor markers for detection of hepatocellular carcinoma. World J Gastroenterol 12: 1175-1181. [PubMed]

56. Song W, Li H, Tao K, Li R, Song Z, et al. (2008) Expression and clinical significance of the stem cell marker CD133 in hepatocellular carcinoma. Int J Clin Pract 62: 1212-1218. [PubMed]

57. Yoshikawa S, Zen Y, Fujii T, Sato Y, Ohta T, et al. (2009) Characterization of CD133 + parenchymal cells in the liver: histology and culture. World $J$ Gastroenterol 15: 4896-4906. [PubMed]

58. Song YJ, Zhang SS, Guo XL, Sun K, Han ZP, et al. (2013) Autophagy 
Citation: Lui SK, Vilchez V, Gedaly R (2015) Liver Cancer Stem Cells: A New Paradigm for Hepatocellular Carcinoma Treatment. J Stem Cell Res Ther 5: 283. doi:10.4172/2157-7633.1000283

contributes to the survival of CD133+ liver cancer stem cells in the hypoxic and nutrient-deprived tumor microenvironment. Cancer Lett 339: 70-81. [PubMed]

59. Hagiwara S, Kudo M, Nagai T, Inoue T, Ueshima K, et al. (2012) Activation of JNK and high expression level of CD133 predict a poor response to sorafenib in hepatocellular carcinoma. Br J Cancer 106: 1997-2003. [PubMed]

60. Yamashita T, Honda M, Nakamoto Y, Baba M, Nio K, et al. (2013) Discrete nature of $\operatorname{EpCAM}(+)$ and $\mathrm{CD} 90(+)$ cancer stem cells in human hepatocellular carcinoma. Hepatology 57: 1484-1497. [PubMed]

61. Thakolwiboon S, Zhu J, Liang Q, Welling TH, Zhang M, etal. (2014) Heterogeneity of The CD90+ Population in Different Stages of Hepatocarcinogenesis. J Proteomics Bioinform 7: 296-302. [PubMed]

62. Lu JW, Chang JG, Yeh KT, Chen RM, Tsai JJ, et al. (2011) Overexpression of Thy1/CD90 in human hepatocellular carcinoma is associated with HBV infection and poor prognosis. Acta Histochem 113: 833-838. [PubMed]

63. Dang H, Steinway SN, Ding W, Rountree CB (2015) Induction of tumor initiation is dependent on CD44s in C-Met(+) hepatocellularcarcinoma. BMC Cancer 15: 161. [PubMed]

64. Mani SA, Guo W, Liao MJ, Eaton EN, Ayyanan A, et al. (2008) The epithelialmesenchymal transition generates cells with properties of stem cells. Cell 133 704-715. [PubMed]

65. Polyak K, Weinberg RA (2009) Transitions between epithelial and mesenchyma states: acquisition of malignant and stem cell traits. Nature Reviews Cancer 9 : 265-273. [PubMed]

66. Thiery JP, Acloque H, Huang RYJ, Nieto MA (2009) Epithelial-mesenchymal transitions in development and disease. Cell 139: 871-890. [PubMed]

67. Yang MH, Chen CL, Chau GY, Chiou SH, Su CW, et al. (2009) Comprehensive analysis of the independent effect of twist and snail in promotingmetastasis of hepatocellular carcinoma. Hepatology 50: 1464-1474. [PubMed]

68. Mima K, Hayashi H, Imai K, Kuroki H, Nakagawa S, et al. (2013) High CD44s expression is associated with the EMT expression profile and intrahepatic dissemination of hepatocellular carcinoma after local ablation therapy. Hepatobiliary Pancreat Sci 20: 429-434. [PubMed]

69. Zhu Z, Hao X, Yan M, Yao M, Ge C, et al. (2010) Cancer stem/progenitor cells are highly enriched in CD133+CD44+ population in hepatocellular carcinoma. Int J Cancer 126: 2067-2078. [PubMed]

70. Fan ST, Yang ZF, Ho DW, Ng MN, Yu WC, et al. (2011) Prediction of posthepatectomy recurrence of hepatocellular carcinoma by circulating cancer stem cells: a prospective study. Ann Surg 254: 569-576. [PubMed]

71. Kelley RK, Magbanua MJ, Butler TM, Collisson EA, Hwang J, et al. (2015) Circulating tumor cells in hepatocellular carcinoma: a pilot study of detection, enumeration, and next-generation sequencing in cases and controls. BMC Cancer 15: 206. [PubMed]

72. Smith LM, Nesterova A, Ryan MC, Duniho S, Jonas M, et al. (2008) CD133/ prominin-1 is a potential therapeutic target for antibody-drug conjugates in hepatocellular and gastric cancers. Br J Cancer 99: 100-109. [PubMed]

73. Zhang L, Li H, Ge C, Li M, Zhao FY, et al. (2014) Inhibitory effects of transcription factor Ikaros on the expression of liver cancer stem cell marke CD133 in hepatocellular carcinoma. Oncotarget 15: 10621-10635. [PubMed]

74. Bach P, Abel T, Hoffmann C, Gal Z, Braun G, et al. (2013) Specific elimination of CD133+ tumor cells with targeted oncolytic measles virus. Cancer Res 73: 865-874. [PubMed]

75. Yang ZF, Ngai P, Ho DW, Yu WC, Ng MNP, et al. (2008) Identification of local and circulating cancer stem cells in human liver cancer. Hepatology 47: 919928. [PubMed]

76. Keating GM, Santoro A (2009) Sorafenib: a review of its use in advanced hepatocellular carcinoma. Drugs 69: 223-240. [PubMed]

77. Clevers $H$, Nusse $R$ (2012) Wnt/B-catenin signaling and disease. Cell 149 : 1192-1205. [PubMed]

78. Clevers $H$ (2011) The cancer stem cell: premises, promises and challenges Nature Medicine 17: 313-319. [PubMed] 